\title{
An overview on ELISA techniques for FMD
}

Li-na Ma, Jie Zhang, Hao-tai Chen, Jian-hua Zhou, Yao-zhong Ding and Yong-sheng Liu*

\begin{abstract}
Background: FMD is one of the major causes of economic loss of cloven-hoofed animals in the world today. The assessment of dominant genotype/lineage and prevalent trends and confirmation the presence of infection or vaccination not only provides scientific basis and first-hand information for appropriate control measure but also for disease eradication and regaining FMD free status following an outbreak. Although different biological and serological approaches are still applied to study this disease, ELISA test based on the distinct format, antigen type and specific antibody reinforce its predominance in different research areas of FMD, and this may replace the traditional methods in the near future. This review gives comprehensive insight on ELISA currently available for typing, antigenic analysis, vaccination status differentiation and surveillance vaccine purity and content at all stages of manufacture in FMDV. Besides, some viewpoint about the recent advances and trends of ELISA reagent for FMD are described here.
\end{abstract}

Methods: More than 100 studies regarding ELISA method available for FMD diagnosis, antigenic analysis and monitor were thoroughly reviewed. We investigated previous sagacious results of these tests on their sensitivity, specificity.

Results: We found that in all ELISA formats for FMD, antibody-trapping and competitive ELISAs have high specificity and RT-PCR (oligoprobing) ELISA has extra sensitivity. A panel of monoclonal antibodies to different sites or monoclonal antibody in combination of antiserum is the most suitable combination of antibodies in ELISA for FMD. Even though from its beginning, $3 A B C$ is proven to be best performance in many studies, no single NSP can differentiate infected from vaccinated animals with complete confidence. Meanwhile, recombinant antigens and peptide derived from FMDV NPs, and NSPs have been developed for use as an alternative to the inactivated virus antigen for security.

Conclusions: There is a need of target protein, which accurately determines the susceptible animal status based on the simple, fast and reliable routine laboratory test. A further alternative based on virus-like particle (VLP, also called empty capsids) in combination of high throughput antibody technique (Phage antibody library/antibody microarray) may be the powerful ELISA diagnostic reagents in future.

\section{Introduction}

Foot and mouth disease(FMD) is a highly contagious and economically devastating disease of cloven-hoofed animals which hold a wide of the host spectrum such as cattle, pigs, sheep, goats, buffalo, deer, antelope and wild pigs and can severely constrain international trade of animals and animal products. FMD is caused by FMD virus (FMDV), a virus in the genus Aphthovirus within the family Picornaviridae [1]. The genome is over $8 \mathrm{~kb}$ in length and encode four structural proteins (SPs, VP1,

\footnotetext{
*Correspondence: liuyongshengvip8@163.com

State Key Laboratory of Veterinary Etiological Biology, National Foot and Mouth Disease Reference Laboratory, Lanzhou Veterinary Research Institute, Chinese Academy of Agricultural Sciences, Lanzhou 730046, China
}

VP2, VP3 and VP4)that form an icosahedrical capsid [2], and a total of ten mature non-structural proteins (NSPs)(L, 2A, 2B, 2C, 3A, 3B, 3C, 3D; or some complex, such as $3 A B$ or $3 A B C)$. Though the genome of FMDV is small, it has a high mutation rate and spontaneous. In FMDV, structural proteins are more variable than nonstructural proteins. Mutations or deletions in structural proteins may help FMDV to evade an immune response produced by the host [3]. Furthermore, the variations are unequally distributed among the four structural proteins, particularly the VP1 protein, which shows the most frequently variability due to its significant roles in virus attachment, protective immunity, and serotype specificity. Antigenically, this virus exists as seven
C Biomed Central

(c) $2011 \mathrm{Ma}$ et al; licensee BioMed Central Ltd. This is an Open Access article distributed under the terms of the Creative Commons Attribution License (http://creativecommons.org/licenses/by/2.0), which permits unrestricted use, distribution, and reproduction in any medium, provided the original work is properly cited. 
distinct serotypes (i.e., O, A, C, Asia 1 and SAT1-3) and multiple subtypes or antigenic variants within each serotype $[4,5]$, which make the vaccine from one serotype does not confer protection against the other serotype. Consequently, vaccine strain requirements differ according to the type and subtypes of virus prevailing globally and the antigenic drift or antigenic shift of circulating virus or field isolates have to be survey on a large scale and matching vaccines have to be selected with care. Currently, vaccination remains the most effective countermeasure against FMDV, but, which complicated the problem of differentiate infected and vaccinated animals. Confront with parallel infection and vaccination, an accurate assessment to susceptible animal in a long range is urgent for determining the following control measures but also difficult due to lack of effective investigation approach. These limitations make the search for stable and safe test become an active area of research. In this review, the ELISA methodology and its utilization in the identification, detection and quantification of viral particle or viral antigens or specific antibodies are discussed. The newly reagent and skills, which show great promise but is still in the early stages of development was described as well.

\section{ELISA for FMDV diagnosis/typing}

Typical Clinical signs of FMD are characterised by a vesicular condition of the feet, buccal mucosa, rhinarium and the mammary glands of the females. Therefore, FMD cannot be differentiated clinically from other vesicular diseases, such as vesicular stomatitis, swine vesicular disease and vesicular exanthema. As a result, laboratory diagnosis of suspected FMD cases became a matter of significance.

Although methods based on virus isolation or the demonstration of FMD viral antigen or nucleic acid in samples of tissue or fluid or culture products is sufficient for a positive diagnosis, in general, the ELISA [6,7] using type-specific serological reagents is the preferred procedure for the detection of FMD viral antigen and identification of viral serotype in the early stages of research. Owing to it is more specific, sensitive and efficient, and it is not impacted by pro- or anti-complement factors [8] the ELISA has access to better development and even replaced complement fixation (CF) in most laboratories in the early research phase of FMD. Contrast to $\mathrm{CF}$ and virus isolation, almost the equivalent, even the higher of sensitivity was achieved in ELISA [9-11]. Different ELISA formats, particularly belonging to indirect ELISA, involved in blocking- or competitionor sandwich-based assays have been playing an increasing important role in the identification of FMDV serotype. The most common practice in the early period of the examination of FMD is that serotype-specific polyclonal antibodies (PAbs) or antiserum [7] to $146 \mathrm{~S}$ (intact FMD virion) antigen of single or each of the seven serotypes of FMDV from rabbit and guinea-pig are used as trapping antibody and detecting antibody to develop a double-antibody sandwich ELISA (DASELISA). In addition, the utilization of pre-coated microplate and freeze-dried reagents greatly extended those assays' applications field and shelf time [12]. However, there is experimental evidence that the similar level of neutralizing antibody against the first FMDV was stimulated by the heterotypic $146 \mathrm{~S}$ particles and homotypic $146 \mathrm{~S}$ particles. This displayed a similarity in the antigenic structure among the different serotypes and might sharply reduce the sensitivity of ELISA, which antibodies to $146 \mathrm{~S}$ were adopted in. Practically, $12 \mathrm{~S}$ particles, produced by mild acid treatment disruption of the $146 \mathrm{~S}$ particle or by heating at $56^{\circ} \mathrm{C}$, appear to be as active as $146 \mathrm{~S}$ in inducing neutralizing antibody in guinea-pig inoculated with $146 \mathrm{~S}$ particles [13-16], though there is a low neutralizing activity. Considering as a part of the $146 \mathrm{~S}$ antigenic site, the $12 \mathrm{~S}$ particles become a fresh substitute antigen for intact virus in serum preparation [11]. Further, an examination based on $12 \mathrm{~S}$ particles was exploited as well [10]. However, a little deficiency existed in the abovementioned procedure is that the samples need to be treated to obtain subunits prior test. Antisera is important for many purposes, but they have some proportion of false-positive reactions or unexpected cross-reactivity owing to complex components. Moreover, the drawback related to limited production and heterogeneity lead to be difficult to standardization and hinder a large-scale application of antisera. As an alternative to guinea-pig or rabbit antisera, appropriate monoclonal antibodies (MAbs) secreted by specific hybridoma cells are considered the most promising of diagnostic reagents in terms of homogeneity and specificity and itself and peroxidase-conjugated can be used as capture antibody and detecting antibody, respectively.

A serotype-specific Mab-based antigen detection ELISA in use at the Istituto Zooprofilatico Sperimentale, Brescia, Italy [17], relies on a mixture of at least 3 different Mabs against each of the serotypes $\mathrm{O}, \mathrm{A}$ and $\mathrm{C}$ to detect FMD virus in clinical samples. And complextrapping-blocking [18] ELISAs using combinations of serotype-specific Mabs have been developed as well. Furthermore, numerous assays were built on the base of combination of PAbs and MAbs or two-MAbs system [19]. But it is worth pointing out that, in most cases, polyclonal antibodies are a better choice as coating antigen in former system and pairs of monoclonal antibodies subjecting to different antigen sites is necessary for the latter. In order to further enhance sensitivity, an approach of trace detection known as RT-PCR (oligoprobing) ELISA $[20,21]$ in both solid and/or aqueous 
phase hybridization formats emerged and illustrated a bright prospect in mild subclinical infection or persistently infected carriers of lacking specific symptoms. Due to the highly contagious nature of FMD, the laboratory diagnosis related to live virus must be done in a laboratory that corresponds with the OIE requirements for Containment Group 4 pathogens. For the purpose of reducing the disease security risk involved compared with the use of live virus, inactivated antigens or trypsin-treated virus or proteins isolated by chemical or enzymic treatment of intact FMDV or recombinant proteins, particularly, the expressed VP1 protein [22] was proven to be a more accurate, safe target to examine FMDV and minimize the occurrence of false-positive results.

Currently, there is a little FMDV antigen detection test that employs the use of serotype-independent crossreactive reagents. To aid improved diagnosis, Muller et al. [23] developed an assay system of serotype-independent FMDV antigen detection of all seven serotypes of FMDV using newly developed chickens antiserum targeting a highly conserved region located within the structural protein $1 \mathrm{AB}$ (accordingly named $1 \mathrm{AB}^{\prime}$ ) [24] and a recently identified cross-serotype reactive monoclonal antibody recognized the $\mathrm{N}$ terminal of $1 \mathrm{~B}$ [25].

\section{ELISA for antigenic profile and epitopes analysis of FMDV}

Owing the characteristics of quasispecies, natural isolate FMD viruses derived from different outbreaks showed much antigenic difference, which generally results in vaccine lacking effective protection against those FMD epidemic strains and even causing FMD outbreak. It is, therefore, an essential part of the epidemiological survey to assess regularly the antigenic characteristics of field isolates. Continuous monitoring of the antigenic relationship of field isolates in relation to the reference vaccine strain will provide an up to date knowledge about the efficacy of the vaccine virus in use and also has access to select the most suitable vaccine strains in case of emergency vaccination. Antigenic profiling by ELISA using panels of well-characterised MAbs [26] is suitable approaches for selecting representative virus isolates for vaccine matching. ELISA also has been used as a rapid method for assessing the relationship of vaccine virus strains with field virus strains collected [27] or those from outbreaks and subsequently, the liquid phase blocking (LPB) ELISA has been in use as an alternative to serum neutralization test (SNT) in determining the protective antibody response $[28,29]$ and assessing the antigenic relationship of field viruses [30,31]. The result obtained in ELISA test was more appropriate towards incorporation of O1/Manisa into the vaccination program [31]. And the use of multiple Mabs has the advantage that it is less likely that a field virus will fail to possess at least one of the epitopes recognised by the antibodies. Antibodies that neutralize viral infectivity provide an important mechanism of protection against FMD. Thus, it is important to define epitopes, especially those ones that elicit the protective immune response and their variation or conservation among variants, subtypes and serotypes. In addition, the analysis of epitopes profile may provide significant reference for studying in aspects of molecular recognition, molecular immunology, particularly in the field of the selection of appropriate candidate vaccine strains. Traditional methods for defining linear antigenic epitopes, especially those neutralizing antigenic sites in more detail, include cloning and sequencing escape mutants [32], fragmentation of proteins either by chemical cleavage or by enzymatic digestion [33], peptide scanned technology based on peptide array or synthesizing a large number of peptides or a set of overlapping peptides corresponding to the known amino acid sequence of a protein [34,35]. Though some antigenic sites in FMD viruses of serotypes $\mathrm{O}, \mathrm{A}$ and $\mathrm{C}$ and other Picornaviruses have identified mainly by abovementioned methods, ELISA- based approach identifying antigenic sites was still developed quickly. In 1985, McCullough et al. [36] firstly reported the usage of the liquid phase ELISA (LP-ELISA) in the FMDV epitope identification. Following, ELISA using single or an overlapping set of peptides has been used to map epitopes on VP1, VP2, VP3, VP4 [37-41]. Recently, another approach to map FMDV-NSP infection-related B-cell epitopes and T-cell epitopes by analyzing overlapping peptides which were used in ELISAs as synthetic peptides [32,42-44] was described.

Since monoclonal antibodies define a specific region, a large number of viruses can be analyzed against a panel of Mab in a single test [45]. Such studies [46-50] provide a rapid measure of the epitope profiles of viruses, because non-reactivity of a particular Mab is indicative of a minor antigenic difference between strains [51]. Nevertheless, a competition ELISA-based approach has been used successfully to define the epitopes of FMDV $[47,52,53]$. For confirmatory purposes, refinements to this approach such as the use of Fab fragments of antibodies or profiling using site-specific mutant viruses should be considered. Furthermore, to estimate the relative proportion of anti-FMDV antibodies with different antigenic site specificities presenting in the antiserum from cattle, swine and sheep, conventionally immunized with O1 serotype vaccine, Aggarwal et al. [54] has used a capture competition ELISA in his work. As described for a non-serotype specific antigen detection ELISA, the identification of an epitope shared between all of the seven serotypes of FMD virus could be the basis of a non-serotype specific competition ELISA able to detect 
antibody to any strain of FMD virus. Due to their highly conserved nature, epitopes on the NSP's of the virus are the most likely candidates for such a site.

\section{ELISA for differentiating infected from vaccinated animals (DIVA)}

Control of FMD mainly encompasses vaccination and slaughter policy, particularly for the FMD-free countries, and slaughter policy is considered a fundamental measure. However, some restrictions from economic situation, social culture, geographical and natural environment limit this policy to be applied in a largescale range in the endemic areas. Consequently, vaccination or the combination policy of vaccination and slaughter remain the most effective countermeasure against FMDV. Though different type of vaccine comprising subunit vaccine, peptide vaccine, DNA vaccine are developed, FMD inactivated vaccine still play a key role in control campaigns and eradication of FMD [55] in the majority FMD epidemic countries and territories because of perfect protection potency. However, another new problem arises from inactivated vaccine of FMD is that it is difficult to distinguish vaccinated from infected animals. And then, A range of ELISA techniques are currently being evaluated with the intention of producing ELISAs for routine diagnostic use which are capable of detecting antibody to FMD virus NSP's. These methods were described as following:

3D Protein 3D, also known as the virus infection associated antigen (VIAA) since antibodies to this antigen would be detected in serum from recovery animals [56], is the core subunit of the virus-encoded RNA-dependent RNA polymerase [57] and responsible for proteolytic cleavage and viral replication [58].

The antigenicity of $3 \mathrm{D}$ protein is highly conserved among all serotypes [59], holding out the possibility of a single serological test capable of detecting infection with any of the seven serotypes of the virus. 3D polymerase is the first NSP to be used to distinguish FMDV infected from vaccinated animals. The traditional VIAA is a semi-purified antigen prepared from the virus grown in tissue culture. When it is used in ELISA, there are problems of inadequate reproducibility appearing to be an inherent characteristic of the semi-purified nature of the VIAA preparations (World Reference Laboratory, unpublished findings). In order to address these problems, recombinant VIAA antigen has considerable attractions. When used in a simple indirect ELISA, recombinant $3 \mathrm{D}$ can differentiate infected from naive cattle [60]. The sensitivity of the test is only slightly lower than the conventional liquid phase blocking ELISA of Hamblin et al. [61] and the specificity is approximately $95 \%$. Moreover, the 3D antibody tests can be used to monitor viral activity in large cattle populations and for certification of FMDV free animals for import and/or export testing [59]. Whereas the following research showed that repeatedly vaccinated animals can develop antibodies to 3D, which demonstrate $3 \mathrm{D}$ is insufficient to differentiate infection from vaccination.

3B Protein 3B, also known as VPg, is the viral genome-bound protein. It exists in three nonidentical copies and covalently bound to the 5 ' end of the genome and serves as a primer for virus genome replication [62]. Besides, the VPg copy number also has a substantial association with the host range and virulence [63]. An epitope-blocking ELISA (EB-ELISA) exploring combination of MAb to $3 \mathrm{~B}$ core repeat motif (QKPLK) and purified recombinant $3 \mathrm{AB}$ protein was developed by Oem et al. [64] to evaluate FMD-free herds and vaccinated cattle, pigs, goats, and sheep in 2007.

$3 \mathrm{ABC}$ The polypeptide $3 \mathrm{ABC}$, playing an important role during the different stages of viral replication [65-67], is perceived by the most researchers as the most appropriate antigen to distinguish infection from vaccination because of its high immunogenicity and relatively low concentration in FMDV-infected cell lysates. Numerous different mode of 3ABC-ELISAs based on the E.coli expression system were developed to discriminate naïve, infected, vaccinated pig/cattle/sheep and detect silent infections/subclinical cases, or survey field samples in FMD-vaccinated or infected populations [68-71]. In order to imitate native protein as far as possible, the NSPs expressed in baculovirus expression systems [58,72,73] was searched. In 2003, Kweon et al. [74] established Mab linked indirect-trapping ELISA using the baculovirus expressed 3ABC (mainly amino acid 1417-1835) and MAb against 3A. The equal sensitivity and specificity were acquired in comparing with commercial kits (baculovirus expressed 3ABC I-ELISA from USDA and Mab (3A) linked E. coli expressed 3ABC IELISA from IZSLE) during retrospective sero-surveillance. Then, Sørensen et al. [75] modified the method of Kweon et al. and removed non-specific reactions in sera of cattle and sheep by filtration and inactivation. Due to the antigen capture strategy can sharply simplify the purification step of recombinant protein, Clavijo et al. [76] established a biotinylated 3ABC competitive ELISA (cELISA), which demonstrated no differences between species (cattle, sheep, pigs) and virus serotypes. Other indirect and competitive ELISAs detecting antibodies to $3 \mathrm{ABC}$ have been shown to have equivalent diagnostic performance characteristic [77,78].

However, the NSPs expressed in E. coli and baculovirus expression systems may sometimes create problems in the interpretation of the results on account of non-specific reactions. Furthermore, the number of epitopes found on such a long recombinant protein may 
interfere with antibodies to other Picornaviruses $[43,79,80]$. Moreover, chemically synthesized synthetic peptides of NSPs were used for DIVA [43,80-82]. Subsequently, Foord et al. [83] provided a C-ELISA format on the basis of complete bacterial expression systems in 2007. The combination of recombinant antibody single chain variable fragments ( $\mathrm{scFv}$ ) from phage display libraries with E.coli-derived recombinant $3 \mathrm{ABC}$ reflected the best performance in detecting sera from cattle, sheep and pigs representing naïve, FMDV-vaccinated or FMDV-infected animals. The biggest advantage of this test is safe, economical and without the need for infectious virus, the use of laboratory animals or the costly maintenance of viable hybridoma cell lines. The results indicated that $\mathrm{scFv}$ displayed the potential to replace polyclonal or monoclonal antibodies in such assays.

Other NSPs or NPs ELISAs based on other NSPs and NPs or assays using infection-specific epitopes of NSPs to remove cross reactivity are being explored $[43,80,81]$. Moreover, chimeric proteins that infection related B-cell epitopes of FMDV NSPs, which self-assembled into chimeric tymovirus-like particles(TVLPs), was selected as a candidate antigen for use in I-ELISA for DIVA of different species from the field [84]. The function of the nonstructural proteins $2 \mathrm{~B}$ is not very clear, although it has hydrophobic domains $[85,86]$. However, a $2 \mathrm{~B}$ peptide ELISA, described by Inoue et al. [42], using a chemically synthesized $2 \mathrm{~B}$ peptide (RSTPEDLERAEKQ) as antigen showed more competitive strength than other NSP tests in the detection of the early period of infection because of the characteristic of earlier induction (as early as 1-2 weeks after infection) and longer persistence of the antibody to 2B. Then, Ko et al. [87] reported rP13C ELISA in 2009, which explored the recombinant protein (rP13C) expressed in insect cells as a diagnostic antigen. The higher endpoint titers than LPB-ELISA and virus neutralization test (VNT) was represented in the measure of sera from goats challenged with FMDV postvaccination.

\section{ELISA for quantification of FMDV}

Usually, the effectiveness or immunogenicity of the vaccine depends to a large extent on the content of $146 \mathrm{~S}$ and the stability of these particles after virus inactivation procedures and formulation into vaccines. In the past, the most common method for the quantification of the FMD whole virus particle is either $\mathrm{CsCl}$, or linear sucrose density centrifugation procedure [88], both of which are labor intensive, time-consuming, require expensive equipment and cannot assess whether the virus has been affected by proteolytic enzymes. In recent years, as a rapid, effective serological method, ELISA, which not only sharply simplified the detection process, but also greatly increased sensitivity and specialty, is emerging crucial and novel application in terms of evaluation the amount of intact virus in vaccine. Moreover, ELISA can simultaneously quantify $146 \mathrm{~S}$ in many samples and monitor whole virus particle in each step of vaccine manufacture as well as being used to test the effects of medium modification and different culture models. Since whole particles and subunits share most of the common epitopes, polyclonal sera against purified $146 \mathrm{~S}$ particles cross react with subunits. In order to overcome above cross-reactivity, one strategy for the specific detection of $146 \mathrm{~S}$ based on pairs and single MAb, which bound only to $146 \mathrm{~S}$ and not to the subunit particle was demonstrated by Van Manaan et al. [89] and Crowther et al. [90] in the presence of virus subunits (12S), respectively. Then, during in-process controls, Alonso et al. [91] quantified antigen mass adopting the panels of MAb to FMD types $\mathrm{O}, \mathrm{A}$ and $\mathrm{C}$ in an indirect sandwich ELISA (IS-ELISA). In 2008, Yang et al. [92] further optimized the method of Van Manaan et al. by employing polyclonal antibodies as the capture antibody and promoted the quantification of $146 \mathrm{~S}$ of FMDV serotype $\mathrm{O}$ and $\mathrm{A}$ to nanogram level. In 2010, Capozzo et al. [93] firstly developed an in-process control filtrationassisted chemiluminometric immunoassay to quantify FMDV non-capsid proteins in vaccine-antigen batches. A detection limit, $2 \mathrm{ng}$ for purified NCP and $4 \mathrm{ng}$ for vaccine-antigen batches spiked with $\mathrm{NCP}$, was gained in this method.

\section{Conclusion}

FMD, which is an acute, contagious disease of clovenhoofed animals, has caused huge economic losses since the finding and is still prevalent in many parts of the world. Though different approaches are used, the ELISA assay has been actively studied in terms of examination, variation, and diagnosis research of FMD. A preliminary study of ELISA was aimed at typing FMDV different serotype, and subsequent was used to identify antigen epitopes and evaluate the relationship or the variant degree between reference virus and isolated strains or circulating strains. Currently, ELISA was designed to exploit their potential in differentiating infected from vaccinated animals or carriers and quantitation virions during different stages of vaccine production, particularly in manufacture of pre-production, in-process and final products test. Although theoretically the detection of antibody to NSP's must indicate infection rather than vaccination, but in practice, antibody against NSPs also might be provoked by trace amounts of NSP's existed in commercial vaccines and multiple vaccinations. Therefore, currently no test has been fully validated. Whereas, a popular viewpoint from international NSP test validation at Brescia is that the usage of multi-NSP test will acquire the most suitable combination of tests and 
increase the efficiency of detection [77,94]. Furthermore, innovation and exploit related to ELISA formats was developed as well. Starting with indirect ELISA, the liquid-phase blocking ELISA (LPBE) $[61,28]$ and the solid-phase competitive ELISA(SPCE) [17,95-97] were advocated. Other trap and competitive ELISAs detecting animal antibody from different species have shown better diagnostic performance. These ELISAs either use purified antigens absorbed directly to microplates or use polyclonal or monoclonal antibodies to trap specific antigens from semi-purified preparations $[69,73,98,99]$.

Regardless of the target (antigens or serum), as the core reagent of ELISA, antibody, particularly a large number of monoclonal antibody against FMD virus different regions of SP and NSP was prepared [100-107]. Accordingly, MAb based ELISAs make advances and improvement, particularly those used in antigen mapping. In order to eliminate cross-reactivity as soon as possible and increase the specificity, an approach combining antiserum from rabbit or guinea-pig and monoclonal antibody was exploited and perform well in the examination of FMD. In addition, antibody produced from non-animals, such as single-chain antibody, may show a bright future as a promising ELISA reagent.

The risk of virus release is the primary consideration for most researchers in the choice of virus antigen. To address this limitation, recombinant proteins and peptide derived from FMDV NPs and NSPs have been developed for alternative to whole-virus and inactivated virus antigen. However, the narrow antigenic epitopes harboring in such antigens have generally been insufficient to either afford solid protection of natural hosts or potent test. But empty capsids maintain continuous and discontinuous B-cell epitopes and T-cell epitopes presenting in authentic virions [108-114] and may induce protective responses similar to those elicited by inactivated virus. At present, empty capsids of FMDV of different serotypes have been obtained by using either Escherichia coli or baculovirus as an expression system $[115,116]$, especially a recent report of the versatility of the baculovirus expression system [117] for the production of P12A3C precursor of FMDV. Therefore, as a further alternative to peptide or simple recombinant protein, empty capsids of FMDV will open new hotspot in the field of both ELISA reagent and vaccine antigen.

\footnotetext{
Acknowledgements

This work was supported in parts by grants from National Science \& Technology Key Project

(2009ZX08007-006B) and International Science \& Technology Cooperation Program of China

(No. 2010DFA32640) and Science and Technology Key Project of Gansu Province (No.

0801NKDA034). This study was also supported by National Natural Science foundation of China
}

(No. 30700597, No. 31072143 and No. 31172335).

\section{Authors' contributions}

LNM contributed to the original draft of the manuscript, and approved the final version. JZ and HTC contributed to conception and design of the manuscript, and involved in revising the manuscript. JHZ and YZD helped to provide information and suggestion. YSL is the corresponding author. All authors read and approved the final manuscript.

\section{Competing interests}

The authors declare that they have no competing interests.

Received: 22 June 2011 Accepted: 4 September 2011

Published: 4 September 2011

\section{References}

1. Belsham GJ: Distinctive features of foot-and-mouth disease virus, a member of the picornavirus family, aspects of virus protein synthesis, protein processing and structure. Prog Biophys Mol Biol 1993, 60:241-260.

2. Mason PW, Grubman MJ, Baxt B: Molecular basis of pathogenesis of FMDV. Virus Res 2003, 91:9-32.

3. Carrillo C, Tulman ER, Delhon G, Lu Z, Carreno A, Vagnozzi A, Kutish GF, Rock DL: Comparative genomics of foot and mouth disease virus. J Virol 2005, 79:6487-6504.

4. Domingo E, Escarmis C, Baranowski E, Ruiz-Jarabo CM, Carrillo E, Nunez Jl, Sobrino F: Evolution of foot-and-mouth disease virus. Virus Res 2003, 91:47-63.

5. Pereira HG: Subtyping of foot and mouth disease virus. Dev Biol Stand 1977, 35:167-174.

6. Ferris NP, Donaldson Al: The World Reference Laboratory for Foot and Mouth Disease: a review of thirty-three years of activity (1958-1991). Rev sci tech Off int epiz 1992, 11:657-684.

7. Roeder PL, Le Blanc Smith PM: Detection and typing of foot-and-mouth disease virus by enzyme-linked immunosorbent assay: a sensitive, rapid and reliable technique for primary diagnosis. Res Vet Sci 1987, 43:225-232.

8. Ferris NP, Dawson M: Routine application of enzyme-linked immunosorbent assay in comparison with complement fixation for the diagnosis of foot-and-mouth and swine vesicular disease. Vet Microbiol 1988, 16:201-209.

9. Hamblin C, Armstrong RM, Hedger RS: A rapid enzyme-linked immunosorbent assay for the detection of foot-and-mouth disease virus in epithelial tissues. Vet Microbiol 1984, 9:435-443.

10. Have P, Lei JC, Schjerning-Thiesen K: An enzyme-linked immunosorbent assay (ELISA) for the primary diagnosis of foot and-mouth disease. Acta Vet Scand 1984, 25:280-296.

11. Smitsaart EN, Saiz JC, Yedloutschnig RJ, Morgan DO: Detection of foot-andmouth disease virus by competitive ELISA using a monoclonal antibody specific for the $12 \mathrm{~S}$ protein subunit from six of the seven serotypes. Vet Immunol Immunopathol 1990, 26:251-265.

12. Ferris NP, Powell H, Donaldson Al: Use of pre-coated immunoplates and freeze-dried reagents for the diagnosis of foot-and-mouth disease and swine vesicular disease by enzyme-linked immunosorbent assay (ELISA). J Virol Methods 1988, 19:197-206.

13. Brown F, Crick L: Application of agar gel diffusion analysis to a study of the antigenic structure of inactivated vaccines prepared from the virus of foot-and-mouth disease. J Immunol 1959, 82:444-447.

14. Ceglowski WS: Antibody response to the noninfectious $7 \mathrm{Mu}$ component of the virus of foot-and-mouth disease. Virology 1965, 25:328-330.

15. Meloen RH, Rowlands DJ, Brown F: Comparison of the antibodies elicited by the individual structural polypeptides of foot-and-mouth disease and polio viruses. J Gen Virol 1979, 45:761-763.

16. Cartwright B, Chapman WG, Brown F: Serological and immunological relationships between the $146 \mathrm{~S}$ and $12 \mathrm{~S}$ particles of foot-and-mouth disease virus. J Gen Virol 1980, 50:369-375.

17. Brocchi E, De Simone F, Bugnetti M, Gamba D, Capucci L: Application of a monoclonal antibody based competition ELISA to the measurement of anti-FMDV antibodies in animal sera. Report, Session of the Research Group of the Standing Technical Committee of the European Commission for the Control of Foot-and-Mouth Disease: 24-25 June, 1990; Lindholm, Denmark 1990, 83-88, (Appendix 14) 
18. Van Maanen C: A complex-trapping-blocking ELISA using monoclonal antibodies and detecting specifically antibodies directed against footand-mouth disease types A, O and C, I. Method and characteristics. Vet Microbiol 1990, 24:171-178.

19. Samuel AR, Knowles NJ, Samuel GD, Crowther JR: Evaluation of a trapping ELISA for the differentiation of foot-and mouth disease virus strains using monoclonal antibodies. Biologicals 1991, 19:299-310.

20. Alexandersen S, Forsyth MA, Reid SM, Belsham GJ: Development of reverse transcription-PCR (oligonucleotide probing) enzyme linked immunosorbent assays for diagnosis and preliminary typing of foot-andmouth disease: a new system using simple and aqueous phase hybridization. J Clin Microbiol 2000, 38:4604-4613.

21. Mohapatra JK, Sanyal A, Hemadri D, Tosh C, Palani G, Rasool TJ, Bandyopadhyay SK: Development and comparison of genome detection assays for the diagnosis of foot-and-mouth disease suspected clinical samples. J Virol Methods 2006, 137:14-20.

22. Wang GH, Du JZ, Cong GZ, Shao JJ, Lin T, Xue HW, Chang HY, Xie QG: Establishment of indirect ELISA diagnose based on the VP1 structural protein of foot-and-mouth disease virus (FMDV) in pigs. Sheng Wu Gong Cheng Xue Bao 2007, 23:961-6.

23. Muller JD, McEachern JA, Bossart KN, Hansson E, Yu M, Clavijo A, Hammond JM, Wang L: Serotype-independent detection of foot-andmouth disease virus. J Virol Methods 2008, 151:146-153.

24. Freiberg B, Höhlich B, Haas B, Saalmüller A, Pfaff E, Marquardt O: Typeindependent detection of foot-and-mouth disease virus by monoclonal antibodies that bind to amino-terminal residues of capsid protein VP2. J Virol Methods 2001, 92:199-205.

25. Yang M, Clavijo A, Suarez-Banmann R, Avalo R: Production and characterisation of two serotype independent monoclonal antibodies against foot-and-mouth disease virus. Vet Immunol Immunopathol 2007, 115:126-134

26. Alonso A, Gomes MD, Ramalho AK, Allende R, Barahona H, Sondhal M, Osorio F: Characterization of foot-and-mouth disease vírus by monoclonal antibodies. Viral Immunol 1993, 6:219-228.

27. Gürhan SI, Gürhan B, Aynagöz G, Ünal N, Ünver G: Characterization of Monoclonal Antibodies Against Foot and Mouth Disease Virus and Determination of Antigenic Variations in Field Strains. TURK J VET ANIM SCl 1999, 23:403-408.

28. Hamblin C, Kitching RP, Donaldson Al, Crowther JR, Barnett IT: Enzymelinked immunosorbent assay (ELISA) for the detection of antibodies against foot-and-mouth disease virus. III. Evaluation of antibodies after infection and vaccination. Epidemiol Infect 1987, 99:733-44.

29. Van Maanen C, Terpstra C: Comparison of a liquid-phase blocking sandwich ELISA and a serum neutralization test to evaluate immunity in potency tests of foot-and-mouth disease vaccines. J Immunol Methods 1989, 124:111-9.

30. Kitching RP, Rendle R, Ferris NP: Rapid correlation between field isolates and vaccine strains of foot-and-mouth disease virus. Vaccine 1988, 6:403-408.

31. Samuel AR, Ouldridge EJ, Arrowsmith AEM, Kitching RP, Knowles NJ: Antigenic analysis of serotype $O$ foot-and-mouth disease virus isolates from the Middle East, 1981 to 1988. Vaccine 1990, 8:390-396.

32. Sun T, Lu P, Wang $X$ : Localization of infection-related epitopes on the non-structural protein $3 A B C$ of foot-and-mouth disease virus and the application of tandem epitopes. J Virol Methods 2004, 119:79-86.

33. Atassi MZ, Singhal RP: Immunochemistry of sperm whale myoglobin. 8 . Specific interaction of peptides obtained by cleavage at proline peptide bonds. Biochemistry 1970, 9(20):3854-61.

34. Geysen HM, Rodda SJ, Mason TJ, Tribbick G, Schoofs PG: Strategies for epitope analysis using peptide synthesis. J Immunol Methods 1987, 102:259.

35. Tribbick G: Multipin peptide libraries for antibody and receptor epitope screening and characterization. J Immunol Methods 2002, 267:27-35, (Review).

36. McCullough KC, Crowther JR, Butcher RN: A liquid-phase ELISA and its use in the identification of epitopes on foot-and-mouth disease virus antigens. J Virol Methods 1985, 11:329-338.

37. Bolwell C, Clarke BE, Parry NR, Ouldridge EJ, Brown F, Rowlands DJ: Epitope Mapping of Foot-and-Mouth Disease Virus with Neutralizing Monoclonal Antibodies. J Gen Virol 1989, 70:59-68.
38. Zamorano P, Wigdorovitz A, Perez-Filgueira DM, Carrillo C, Escribano JA, Sadir AM, Borca MV: A 10-aminoacid linear sequence of VP1 of foot and mouth disease virus (FMDV) containing $B$ and T-cell epitopes induces protection in mice. Virology 1995, 212:614-621.

39. Filgueira MP, Wigdorovitz A, Romera A, Zamorano P, Borca MV, Sadir AM: Detection and Characterization of Functional T-Cell Epitopes on the Structural Proteins VP2, VP3, and VP4 of Foot and Mouth Disease Virus O1 Campos. Virology 2000, 271:234-239.

40. Mateu MG, Camarero JA, Giralt E, Andreu D, Domingo E: Direct evaluation of the immunodominance of a major antigenic site of foot-and-mouth disease virus in a natural host. Virology 1995, 206:298-306.

41. Zhang $Z W$, Zhang $Y G$, Wang $Y L$, Pan $L$, Fang $Y Z$, Jiang $S T$, Lü JL, Zhou P: Screening and identification of $B$ cell epitopes of structural proteins of foot-and-mouth disease virus serotype Asia 1. Vet Microbiol 2010, 140:25-33

42. Inoue T, Parida S, Paton DJ, Linchongsubongkoch W, Mackay D, Oh Y, Aunpomma D, Gubbins S, Saeki T: Development and evaluation of an indirect enzyme-linked immunosorbent assay for detection of foot-andmouth disease virus nonstructural protein antibody using a chemically synthesized 2B peptide as antigen. J Vet Diagn Invest 2006, 18:545-552.

43. Höhlich BJ, Wiesmüler KH, Schlapp T, Haas B, Pfaff E, Saalmüller A: Identification of foot-and-mouth disease virus-specific linear B-cell epitopes to differentiate between infected and vaccinated cattle. J Virol 2003, 77:8633-9.

44. Blanco E, Garcia-Briones M, Sanz-Parra A, Gomes P, De Oliveira E, Valero ML, Andreu $D$, Ley $V$, Sobrino F: Identification of T-cell epitopes in nonstructural proteins of foot-and mouth disease virus. J Virol 2001, 75:3164-3174.

45. Crowther JR: The use of monoclonal antibodies in the molecular typing of animal viruses. Rev Sci Tech Off Int Des Epiz 1993, 12:369-383.

46. Robertson BH, Morgan DO, Moore DM: Location of neutralizing epitopes defined by monoclonal antibodies generated against the outer capsid polypeptide, VP1, of foot-and-mouth disease virus A12. Virus Res 1984, 1:489-500

47. McCullough KC, Crowther JR, Carpenter WC, Broochi E, Capucci L, de Simone F, Xie Q, McCahon D: Epitopes on foot-and-mouth disease virus particles. I. Topology. Virology 1987, 157:516-525.

48. Mateu MG, Da Silva JL, Rocha E, De Brum DL, Alonso A, Enjuanes L, Domingo $\mathrm{E}$, Barahona $\mathrm{H}$ : Extensive antigenic heterogeneity of foot-andmouth disease virus of serotype C. Virology 1988, 167:113-24.

49. Moore DM, Vakharia VN, Morgan DO: Identification of virus neutralizing epitopes on naturally occurring variants of type A12 foot-and-mouth disease virus. Virus Res 1989, 14:281-295.

50. Tosh C, Venkataramanan R, Pattnaik B, Hemadri D, Sanyal A: Monoclonal antibodies to an Indian strain of type A foot-and-mouth disease virus. Acta Virologica 1999, 43:219-225.

51. Kitching RP, Knowles NJ, Samuel AR, Donaldson Al: Development of footand-mouth disease virus strain characterization. Trop Anim Health Prod 1989, 21:153-166.

52. Thomas AAM, Woortmeijer RJ, Barteling SJ, Meloen RH: Evidence for more than one important, neutralizing site on foot-and-mouth disease virus. Arch Virol 1988, 99:237-242.

53. Barnett PV, Samuel AR, Pullen L, Ansell D, Butcher RN, Parkhouse RME: Monoclonal antibodies, against $\mathrm{O} 1$ serotype foot-and-mouth disease virus, from a natural bovine host, recognize similar antigenic features to those defined by the mouse. J Gen Virol 1998, 79:1687-1697.

54. Aggarwal N, Barnett PV: Antigenic sites of foot-and-mouth disease virus (FMDV): an analysis of the specificities of anti-FMDV antibodies after vaccination of naturally susceptible host species. J Gen Virol 2002, 83:775-782.

55. Doel TR: FMD vaccines. Virus Res 2003, 91:81-89.

56. Cowan KM, Graves $\mathrm{JH}$ : A third antigenic component associated with footand mouth disease infection. Virology 1966, 30:528-540.

57. Flanegan JB, Baltimore D: Poliovirus-specific primer-dependent RNA polymerase able to copy poly(A). Proc Natl Acad Sci USA 1977, 74:3677-3680.

58. Clavijo A, Wright $P$, Kitching P: Developments in diagnostic techniques for differentiating infection from vaccination in foot-and-mouth disease. Vet J 2004, 167:9-22.

59. O'Donnel VK, Boyle DB, Sproat K, Fondevila NA, Forman A, Schudel A, Smitsaart EN: Detection of antibodies against foot-and-mouth disease 
virus using a liquid-phase blocking sandwich ELISA (LBPE) with a bioengineered 3D protein. J Vet Diagn Invest 1996, 8:143-150.

60. Villinger $F$, Mueller HK, Bruckner $L$, Ackermann M, Kih U: Antibodies to foot-and-mouth disease virus infection associated (VIA) antigen: use of a bioengineered VIA protein as antigen in an ELISA. Vet Microbiol 1989, 20:235-246.

61. Hamblin C, Barnett ITR, Hedger RS: A new enzyme linked immunosorbent assay (ELISA) for the detection of antibodies against FMD virus. 1. Development and method of ELISA. J Immunol Methods 1986, 93:115-121.

62. Paul AV, van Boom JH, Filippov D, Wimmer E: Protein-primed RNA synthesis by purified poliovirus RNA polymerase. Nature 1998 393:280-284

63. Pacheco JM, Henry TM, O'Donnell VK, Gregory JB, Mason PW: Role of nonstructural proteins $3 \mathrm{~A}$ and $3 \mathrm{~B}$ in host range and pathogenicity of foot-and-mouth disease virus. J Virol 2003, 77:13017-13027.

64. Oem JK, Chang BS, Joo HD, Yang MY, Kim GJ, Park JY, Ko YJ, Kim YJ, Park JH, Joo YS: Development of an epitope-blocking-enzyme-linked immunosorbent assay to differentiate between animals infected with and vaccinated against foot-and-mouth disease virus. J Virol Methods 2007, 142:174-181.

65. Ryan MD, Belsham GJ, King AMQ: Specificity of enzyme substrate interactions in foot-and-mouth disease virus polyprotein processing. $J$ Virol 1989, 174:10-15.

66. Xiang W, Andino AV, Wimmer E: RNA signals in entero-and rhinovirus genome replication. Semin Virol 1997, 8:256-273.

67. O'Donnell VK, Pacheco JM, Henry TM, Mason PW: Subcellular distribution of the foot-and-mouth disease virus $3 \mathrm{~A}$ protein in cells infected with viruses encoding wild-type and bovine-attenuated forms of 3A. Virology 2001, 287:151-162

68. Rodriguez A, Dopazo J, Saiz JC, Sobrino F: Immunogenicity of nonstructural proteins of foot-and-mouth disease virus: differences between infected and vaccinated swine. Arch Virol 1994, 136:123-131.

69. Diego DM, Brocchi E, Mackay D, Simone DF: The non-structural polyprotein $3 A B C$ of foot-and-mouth disease virus as a diagnostic antigen in ELISA to differentiate infected from vaccinated cattle. Arch Virol 1997, 142:2021-2033.

70. Brocchi E, De Diego MI, Berlinzani A, Gamba D, De Simone F: Diagnostic potential of mab-based ELISAs for antibodies to non-structural proteins of foot-and-mouth disease virus to differentiate infection from vaccination. Vet Q 1998, 20(Suppl 2):S20-S24.

71. Blanco E, Romero LJ, Harrach ME, Sanchez-Vizcaino JM: Serological evidence of FMD subclinical infection in sheep population during the 1999 epidemic in Morocco. Vet Microbio/ 2002, 85:13-21.

72. Mezencio JM, Babcock GD, Meyer RF, Lubroth J, Salt JS, Newman JF, Brown F: Differentiating foot-and-mouth disease virus-infected from vaccinated animals with baculovirus-expressed specific proteins. Vet $Q$ 1998, 20(Suppl 2):S11-3.

73. Sorensen KJ, Madsen KG, Madsen ES, Salt JS, Nqindi J, Mackay DKJ: Differentiation of infection from vaccination in foot-and-mouth disease by the detection of antibodies to the non-stuctural proteins 3D, 3AB and $3 A B C$ in ELISA using antigens expressed in baculovirus. Arch Virol 1998, 143:1461-1476.

74. Kweon YH, Ko YJ, Kim WII, Lee SY, Naha JJ, Lee KN, Sohna HJ, Choi KS, Hyuna BH, Kanga SW, Joo YS, Lubroth J: Development of a foot-andmouth disease NSP ELISA and its comparison with differential diagnostic methods. Vaccine 2003, 21:1409-1414

75. Sørensen KJ, De Stricker K, Dyrting KC, Grazioli S, Haas B: Differentiation of foot-and-mouth disease virus infected animals from vaccinated animals using a blocking ELISA based on baculovirus expressed FMDV $3 A B C$ antigen and a $3 A B C$ monoclonal antibody. Arch Virol 2005, 150:805-814.

76. Clavijo A, Zhou EM, Hole K, Galic B, Kitching P: Development and use of a biotinylated $3 A B C$ recombinant protein in a solid-phase competitive ELISA for the detection of antibodies against foot-and-mouth disease virus. J Virol Methods 2004, 120:217-227.

77. Brocchi E, Bergmann IE, Dekker A, Paton DJ, Sammin DJ, Greiner M, Grazioli S, de Simone F, Yadin H, Haas B, Bulut N, Malirat V, Neitzert E, Goris N, Parida S, Sorensen K, de Clercq K: Comparative evaluation of six ELISAs for the detection of antibodies to the non-structural proteins of foot-and-mouth disease virus. Vaccine 2006, 24:6966-79.

78. Lu Z, Cao Y, Guo J, Qi S, Li D, Zhang Q, Ma J, Chang H, Liu Z, Liu X, Xie Q: Development and validation of a $3 A B C$ indirect ELISA for differentiation of foot-and-mouth disease virus infected from vaccinated animals. Vet Microbiol 2007, 125:157-169.

79. Silberstein E, Kaplan G, Taboga O, Duffy S, Palma E: Foot-and-mouth disease virus-infected but not vaccinated cattle develop antibodies against recombinant 3AB1 non-strucutural protein. Arch Virol 1997, 142:795-805

80. Meyer RF, Babcock GD, Newman JF, Burrage TG, Toohey K, Lubroth J, Brown F: Baculovirus expressed $2 \mathrm{C}$ of foot-and-mouth disease virus has the potential for differentiating convalescent from vaccinated animals. J Virol Methods 1997, 65:33-43.

81. Oem JK, Kye SJ, Lee KN, Park JH, Kim YJ, Song HJ, Yeh M: Development of synthetic peptide ELISA based on nonstructural protein $2 \mathrm{C}$ of foot and mouth disease virus. J Vet Sci 2005, 6:317-25.

82. Shen F, Chen PD, Walfield AM, Ye J, House J, Brown F, Wang CY: Differentiation of convalescent animals from those vaccinated against foot-and-mount disease by a peptide ELISA. Vaccine 1999, 17:3039-49.

83. Foord AJ, Muller JD, Yu M, Wang LF, Heine HG: Production and application of recombinant antibodies to foot-and mouth disease virus non-structural protein 3ABC. J Immunol Methods 2007, 321:142-151.

84. Hema M, Nagendrakumar SB, Yamini R, Chandran D, Rajendra L, Thiagarajan D, Parida S, Paton DJ, Srinivasan VA: Chimeric tymovirus-like particles displaying foot-and-mouth disease virus non-structural protein epitopes and its use for detection of FMDV-NSP antibodies. Vaccine 2007, 25:4784-4794.

85. Forss S, Strebel K, Beck E, Schaller H: Nucleotide sequence and genome organization of foot-and-mouth disease virus. Nucleic Acids Res 1984, 12:6587-6601.

86. Robertson BH, Grubman MJ, Weddell GN, Moore DM, Welsh JD, Fischer T, Dowbenko DJ, Yansura DG, Small B, Kleid DG: Nucleotide and amino acid sequence coding for polypeptides of foot-and mouth disease virus type A12. J Virol 1985, 54:651-660.

87. Ko YJ, Jeoung HY, Lee HS, Chang BS, Hong SM, Heo EJ, Lee KN, Joo HD, Kima SM, Park JH, Kweon CH: A recombinant protein-based ELISA for detecting antibodies to foot-and-mouth disease virus serotype Asia 1. J Virol Methods 2009, 159:112-118.

88. Doel TR, Fletton B, Staple RF: Further developments in the quantification of small RNA viruses by UV photometry of sucrose density gradients. Dev Biol Stand 1982, 50:209-219.

89. Van Maanen C, Terpstra C: Quantification of intact $146 \mathrm{~S}$ foot-and-mouth disease antigen for vaccine production by a double antibody sandwich ELISA using monoclonal antibodies. Biologicals 1990, 18:315-319.

90. Crowther JR, Reckziegel PO, Prado JA: Quantification of whole virus particles (146S) of foot-and-mouth disease virus in the presence of virus subunits (12S), using monoclonal antibodies in a sandwich ELISA. Vaccine 1995, 13:1064-75.

91. Alonso A, Darsie GC, Teixeira AC, Reis JL, Mesquita JA: Application of monoclonal antibodies to quality control of foot-and-mouth disease. Vaccine 1994, 12:682-686

92. Yang $\mathrm{M}$, Holland $\mathrm{H}$, Clavijo A: Production of monoclonal antibodies against whole virus particles of foot-and-mouth disease virus serotype $O$ and $A$ and their potential use in quantification of intact virus for vaccine manufacture. Vaccine 2008, 26:3377-3382.

93. Capozzo AV, Martínez MR, Schielen WJG: Development of an in process control filtration-assisted chemiluminometric immunoassay to quantify foot and mouth disease virus (FMDV) non-capsid proteins in vaccineantigen batches. Vaccine 2010, 28:6647-6652.

94. Robiolo B, Seki C, Fondevilla N, Grigera P, Scodeller E, Periolo O, La Torre J, Mattion N: Analysis of the immune response to FMDV structural and nonstructural proteins in cattle in Argentina by the combined use of liquid phase and 3ABC-ELISA tests. Vaccine 2006, 13:997-1008.

95. Chenard G, Miedema K, Moonen P, Schrijver RS, Dekker A: A solid-phase blocking ELISA for detection of type $O$ foot-and-mouth disease virus antibodies suitable for mass serology. J Virol Methods 2003, 107:89-98.

96. Mackay DKJ, Bulut AN, Rendle T, Davidson F, Ferris NP: A solid-phase competition ELISA for measuring antibody to foot-and-mouth disease virus. J Virol Methods 2001, 97:33-48.

97. Paiba GA, Anderson J, Paton DJ, Soldan AW, Alexandersen S, Corteyn M, Wilsden G, Hamblin P, Mackay DK, Donaldson Al: Validation of a foot-andmouth disease antibody screening solid phase competition ELISA (SPCE). J Virol Methods 2004, 115:145-158. 
98. Bergmann IE, Malirat V, Neitzert E, Panizutti N, Sanchez C, Falczuk A Improvement of serodiagnostic strategy for foot and mouth disease virus surveillance in cattle under systematic vaccination: a combined system of an indirect ELISA-3ABC with an enzyme-linked immunoelectrotransfer blot. Arch Virol 2000, 145:473-489.

99. Mackay DKJ, Forsyth MA, Davies PR, Berlinzani A, Belsham GJ, Flint M, Ryan MD: Differentiating infection from vaccination in foot-and-mouth disease using a panel of recombinant, nonstructural proteins in ELISA. Vaccine 1998, 16:446-459.

100. McCullough KC, Butcher R: Monoclonal antibodies against foot-andmouth disease virus $146 \mathrm{~S}$ and $12 \mathrm{~S}$ particles. Arch Virol 1982, 74:1-9.

101. Butchaiah G, Rao BU: Hybridoma cell lines secreting monoclonal antibodies to foot-and-mouth disease virus type Asia-1. Acta Virol 1989, 33:121-130.

102. Butchaiah G, Card JL, Morgan DO: Antigenic relationships of foot-andmouth disease virus serotype Asia- 1 isolates demonstrated by monoclonal antibodies. Vet Immunol Immunopathol 1992, 30:275-292.

103. Crowther JR, Rowe CA, Butcher R: Characterization of monoclonal antibodies against a type SAT2 foot-and-mouth disease virus. Epidemiol Infect 1993, 111:391-406.

104. Grazioli S, Fallacara F, Brocchi E: Mapping of neutralizing sites on FMD virus type Asia-1 and relationships with sites described in other serotypes. Report of the Session of the Research Group of the Standing Committee of the European Commisssion of Foot and Mouth Disease: 2003 2003, 277-287.

105. Yang M, Clavijo A, Li M, Hole K, Holland H, Wang H, Deng MY: Identification of a major antibody binding epitope in the non-structural protein 3D of foot-and-mouth disease virus in cattle and the development of a monoclonal antibody with diagnostic applications. J Immunol Methods 2007, 321:174-181.

106. Rana SK, Bagchi T: Development and characterization of monoclonal antibodies against FMD virus type Asia-1 and determination of antigenic variations in the field strains. Vet Immunol Immunopathol 2008, 122:241-249.

107. Ma L, Liu Y, Ding Y, Chen H, Zhou J, Liu W, Wang M, Zhang J: Preparation and characterization of neutralizing monoclonal antibodies against FMDV serotype 0 with synthetic peptide antigen. Hybridoma 2010, 29:409-412.

108. Grubman MJ, Morgan DO, Kendall J, Baxt B: Capsid intermediates assembled in a foot-and-mouth disease virus genome RNA-programmed cell-free translation system and in infected cells. J Virol 1985, 56:120-126.

109. Rweyemamu MM, Terry G, Pay TWF: Stability and immunogenicity of empty particles of foot-and-mouth disease virus. Arch Virol 1979, 59:69-79.

110. Collen T, DiMarchi R, Doel T: A T cell epitope in VP1 of foot-and-mouth disease virus is immunodominant for vaccinated cattle. J Immunol 1991, 146:749-755.

111. Collen T, Doel TR: Heterotypic recognition of foot-and-mouth disease virus by cattle lymphocytes. J Gen Virol 1990, 71:309-315.

112. Rodriguez A, Saiz JC, Novella IS, Andreu D, Sobrino F: Antigenic specificity of porcine $T$ cell response against foot-and-mouth disease virus structural proteins: Identification of T helper epitopes in VP1. Virology 1994, 205:24-33.

113. Saiz JC, Rodriguez A, Gonzalez M, Alonso F, Sobrino F: Heterotypic lymphoproliferative response in pigs vaccinated with foot-and-mouth disease virus. Involvement of isolated capsid proteins. J Gen Virol 1992, 73:2601-2607.

114. Sáiz JC, Cairó J, Medina M, Zuidema D, Abrams C, Belsham GJ, Domingo E, Vlak JM: Unprocessed foot-and-mouth disease virus capsid precursor displays discontinuous epitopes involved in viral neutralization. J Virol 1994, 68:4557-4564.

115. Lewis SA, Morgan DO, Grubman MJ: Expression, processing, and assembly of foot-and-mouth disease virus capsid structures in heterologous systems: induction of a neutralizing antibody response in guinea pigs. J Virol 1992, 65:6572-6580

116. Roosien J, Belsham GJ, Ryan MD, King AMQ, Vlak JM: Synthesis of footand-mouth disease virus capsid proteins in insect cells using baculovirus expression vectors. J Gen Virol 1990, 71:1703-1711.

117. Li Z, Yi Y, Yin X, Zhang Z, Liu J: Expression of foot-and-mouth disease virus capsid proteins in silkworm-baculoviru expression system and its utilization as a subunit vaccine. PloS One 2008, 3(5):e2273.
doi:10.1186/1743-422X-8-419

Cite this article as: Ma et al:: An overview on ELISA techniques for FMD. Virology Journal 2011 8:419.

\section{Submit your next manuscript to BioMed Central and take full advantage of:}

- Convenient online submission

- Thorough peer review

- No space constraints or color figure charges

- Immediate publication on acceptance

- Inclusion in PubMed, CAS, Scopus and Google Scholar

- Research which is freely available for redistribution 